\title{
The Effect of Caloric Supplementation on Selected Milk Protective Factors in Undernourished Guatemalan Mothers
}

\author{
M. VERÓNICA HERIAAS, JOSĖ R. CRUZ. TERESA GONZȦLEZ-COSSIO. \\ FEDERICO NAVE, BARBRO CARLSSON, AND LARS $\AA$. HANSON \\ Institute for Nutrition of C'entral America and Panama. Guatemala (ity: Guatemala: and the Department of \\ Clinical Immunology: University of Götehorg. Goteborg. Sweden
}

\begin{abstract}
The level and avidity indices of specific antibodies against tetanus toxoid, Escherichia coli $\mathrm{O6}$ and a pool of 10 common $E$. coli $O$ antigens, as well as the concentration and daily output of lactoferrin and total secretory IgA (SIgA), were evaluated in the milk of moderately undernourished mothers who were in a random blind design divided into two groups and given different caloric supplementations. Group A received a high caloric supplement $(500 \mathrm{kcal} / \mathrm{d})$, and group $B$ received a low caloric supplement $(140 \mathrm{kcal} / \mathrm{d})$. Determinations were done using ELISA in various modifications, except for lactoferrin, which was quantified by single radial immunodiffusion. The avidity indices were investigated as an evaluation of the antibody quality. In all the parameters evaluated, the only difference found between the two groups at the end of the supplementation period was in the content of total SIgA, which was lower in group B, both in concentration and daily output. However, the SIgA remained within the normal range. Increases as well as decreases in the levels of specific IgA antibodies occurred within both groups. Avidity was decreased in group B only against one of the antigens tested. We conclude that moderate undernutrition does not impair the levels of milk antibodies, and supplementation does not enhance them but prevents the decrease in the content of total milk SIgA. There is a suggestion that the avidity of certain antibody specificities could be hampered. (Pediatr Res 34: 217-221, 1993)
\end{abstract}

\section{Abbreviations}

SIgA, secretory $\operatorname{IgA}$

$\mathrm{KSCN}$, potassium thiocyanate

Several studies have shown the importance of human milk for the overall development in the young infant, not only by providing a well-balanced amount of nutrients, including large quantities of proteins $(1,2)$, but also by protecting against infections (3-5). SIgA is the main Ig in human milk and one of the major factors responsible for the protective effect $(5-7)$. Lactoferrin is another protein present in human milk that, synergistically with SIgA, has a bacteriostatic effect against several bacterial pathogens in vitro $(1,8)$

Malnutrition, including protein and protein-energy deficiency, affects the immune response and therefore might aggravate susceptibility to and the outcome of some infections $(9,10)$. Cell-

Received October 12, 1992: accepted March 25, 1993

Correspondence: Mayra Verónica Herias. Department of Clinical Immunology, Guldhedsgatan 10. S-413 46, Göteborg. Sweden. and antibody-mediated mechanisms $(11,12)$ as well as macrophage function (13) can be affected. Undernutrition has been shown to impair the SIgA system in children $(14,15)$, but this effect has not been clearly demonstrated for the $\mathrm{S} \lg \mathrm{A}$ in human milk. Previous studies on the SIgA quantity in breast milk of undernourished mothers have been cross-sectional and regularly included limited numbers of subjects (16). In general, the findings reported indicate that malnourished women are able to produce and transfer milk-specific SIgA antibodies (17-19) and total SIgA $(16,20,21)$ to their infants in amounts comparable to those of well-nourished mothers. On the other hand. significantly decreased levels of colostral IgA in undernourished mothers have also been reported (22).

In addition to the investigation of levels of total milk SIgA and specific IgA antibodies, which have thus far been used to evaluate the immunologic quality of human milk, in the present study, we measured avidity, or relative affinity, as an estimation of the functional quality of the antibodies. This term is defined as the summation of forces involved in the multivalent antigenantibody interaction (23). Data available demonstrate the superiority of high-affinity antibodies over low-affinity ones in certain biologic reactions (24). Here, we report the findings of the first controlled, longitudinal study to explore whether caloric supplementation during lactation affects the formation of milk SIgA. specific milk IgA antibodies, and lactoferrin in the human.

\section{MATERIALS AND METHODS}

Subjects. The subjects of the study were undernourished mothers living in the poorest sections of Quetzaltenango, in the western Guatemalan highlands, and its surrounding rural areas. The number of women in this study was 67 of the original 102 (González-Cossio et al., unpublished manuscript). The characteristics of the included and the remaining ones were the same. By mean, the subjects included weighed $41.8 \pm 3.8 \mathrm{~kg}$ in group $A$ and $43 \pm 2.9 \mathrm{~kg}$ in group B. were $143.1 \pm 5.0 \mathrm{~cm}$ tall in group $A$ and $143.6 \pm 5.0 \mathrm{~cm}$ in group $B$, and had a calf circumference of $29.5 \pm 1.4 \mathrm{~cm}$ in group A and $29.5 \pm 1.2 \mathrm{~cm}$ in group B. Women with a low calf circumference during the last trimester of pregnancy were invited to the study and recruited, after informed consent. Calf circumference was the most sensitive indicator of undernutrition in women from a similar environment $(25,26)$.

The women were randomized in a double-blind design into one of two groups, A and B. Starting on the 5th wk postpartum. mothers in group A were given high-caloric cookies $(250 \mathrm{kcal} /$ $\mathrm{U})$, while mothers in group $\mathrm{B}$ received low-caloric cookies ( 70 $\mathrm{kcal} / \mathrm{U}$ ); both types of cookies looked identical. The supplement was two cookies per day, Monday to Saturday, delivered to the mothers' homes by community distributors. Supplement consumption was monitored daily by direct observation. The women 
were advised to consume the supplement in addition to their usual diets. The overall difference in caloric intake attributed to the supplement was $269 \mathrm{kcal} / \mathrm{d}$ between the two groups. The original protocol was planned to evaluate the effect of supplementation of undernourished lactating women on their milk production (González-Cossio et al., unpublished manuscript).

Milk samples. The samples were obtained at 5, 10, 20, and 25 wk postpartum, i.e. $0,5,15$, and $20 \mathrm{wk}$ after initiation of the supplement. The procedure was as follows: mothers were invited to the study clinic where they spent 28 consecutive $h$. During this period, the $24-\mathrm{h}$ milk volume was estimated by the testweighing method, and $2 \mathrm{~h}$ after the last feeding, the left breast was totally emptied by extraction with mechanical or batteryoperated breast pumps. The milk samples were placed in glass containers, frozen at $-20^{\circ} \mathrm{C}$ and transported to the central laboratory at the Institute for Nutrition of Central America and Panama. The frozen specimens were thawed and homogenized by sonication. A frozen aliquot was taken for this study, defatted, frozen again, and not thawed until its analysis.

In total, 1718 analyses were done on 243 samples, 887 on group A and 831 on group B. The four consecutive samples collected were not always available from each mother. For the studies of the milk antibodies to the Escherichia coli $\mathrm{O}$ antigen pool, only those who had all the four determinations were selected. The mean number of samples investigated at different times during lactation in group A was 28 (range 16-39) and in group B was 23 (range 15-31). In SIgA and lactoferrin determinations, only the samples at wk 5 and 25 were investigated.

Antigens. To evaluate the effects of undernutrition on milk antibodies, we selected two heat-extracted lipopolisaccharide antigens (27), from E. coli, $\mathrm{O} 6$ and a pool of $\mathrm{O} 1, \mathrm{O} 2, \mathrm{O} 4, \mathrm{O} 6, \mathrm{O} 7$, $\mathrm{O} 8, \mathrm{O} 18, \mathrm{O} 22, \mathrm{O} 25$, and $\mathrm{O} 75$ (abbreviated as "10 pool") and the tetanus toxoid, protein antigen, (kindly provided by Dr. I Heron at the State Serum Institute, Copenhagen, Denmark).

Determination of levels and avidity indices of $\mathrm{IgA}$ antibodies. The levels of specific IgA to the above antigens were measured using the ELISA (28). Quantifications were done in 96-well Dynatech Immunolon II plates (Alexandria, VA) coated with $100 \mu \mathrm{L}$ of the antigen in each well. The $E$. coli antigens were diluted before coating in PBS, pH 7.2, to a concentration corresponding to about $2 \times 10^{9}$ bacteria $/ \mathrm{mL}$; the tetanus antigen was diluted to approximately $6 \mu \mathrm{g} / \mathrm{mL}$. The plates were left overnight at room temperature in a moist chamber, then washed three times with PBS $+0.05 \%$ Tween 20 (Merck Darmstadt, Germany). The samples to be analyzed were thawed and diluted 2fold, beginning with $1: 8$. One hundred $\mathrm{mL}$ of each of the dilutions were added in duplicate wells. Readings were done at $405 \mathrm{~nm}$ in a Titertek Multiscan MCC/340 (Flow Labs, Ayrshire, Scotland), usually after $50 \mathrm{~min}$, but all the OD were determined by extrapolating to $100 \mathrm{~min}$. The reading of the samples was expressed in percentage of a human milk standard pool.

The relative affinity, or antibody avidity index determinations were done by a modification of the ELISA, using KSCN for the elution of antibodies (29). The samples were administered in duplicate wells at the optimal dilution found at the titer determinations. KSCN diluted in PBS-Tween solution was added and incubated at seven different molarities, ranging from 0.25 to 4 M. The plates were read at $100 \mathrm{~min}$. A standard milk sample was always run in each plate. The molarity of $\mathrm{KSCN}$ required to elute $50 \%$ of the antibodies was taken as the measure of relative antibody affinity, or avidity index (30).

Quantification of SIgA and lactoferrin. The method used was a modification of the ELISA assay described for quantification of SIgA $(28,31)$, where soft polyvinyl chloride plates (Dynatech) were directly coated with anti-F $\left(\mathrm{ab}^{\prime}\right)_{2} \alpha$-chain, (Dakopatts, Copenhagen, Denmark). The conjugate was an antisecretory component (Seward Laboratories, London, UK), linked to alkaline phosphatase (Boehringer-Mannheim; Mannheim, Germany). Samples were read against a known standard (human milk pool, with a concentration of $3.0 \mathrm{~g} / \mathrm{L}$ ). The normal levels reported for this protein are between 0.5 and $1.0 \mathrm{~g} / \mathrm{L}(1,32)$.

The single radial immunodiffusion test (33) was used with rabbit antihuman lactoferrin (Dakopatts AS, Copenhagen, Denmark). A human lactoferrin standard with a concentration of 10 g/L (Serva, Feinbiochemica, Heidelberg, Germany) was used to plot the reference curve for each plate. The normal concentration reported in milk for healthy mothers is 1 to $3 \mathrm{~g} / \mathrm{L}(1,32)$. The determinations for SIgA and lactoferrin were done only on the milk samples at wk 5 and 25 .

Statistical analysis. The treatment effect within each group, i.e. a central tendency value different from zero was evaluated using the Wilcoxon signed rank test. The evaluation was performed of the individual differences, i.e. the value at the last determination ( $25 \mathrm{wk}$ postpartum) subtracted with the value for the first determination ( $5 \mathrm{wk}$ postpartum) for each of the groups. The same approach was used to evaluate the effect of supplementation between other weeks (wk 10 to 5, 20 to 5, 20 to 10 , 25 to 10 , and 25 to 20 ) (34).

To test a difference between the two supplemented groups (A and B), the Mann-Whitney $U$ test was used. This method was applied to the individual differences (for wk 25 and 5 postpartum, as explained above) of one group against the other. Only twotailed tests were used (34).

The groups were compared per individual differences. Still, medians are provided in the tables to show the weight of the balance in the groups at different times.

\section{RESULTS}

Lactoferrin concentration and daily output. The concentration of lactoferrin in milk did not differ between the two groups of women, either at the beginning or at the end $(p>0.05)$ of the supplementation period, but decreased significantly at wk 25 ( $p$ $<0.05$; Table 1). Both groups of mothers also had similar daily outputs of lactoferrin at wk 5 and 25 and, despite the decrease observed in lactoferrin concentration during the study period, the daily output remained unchanged (Table 1).

SIgA concentration and daily output. The concentrations of

Table 1. Concentration of lactoferrin and total secretory $\operatorname{IgA}$ in $g / L$ measured at wk 5 and 25 postpartum and statistical analysis of effect of supplementation*

\begin{tabular}{|c|c|c|c|c|c|c|c|c|c|}
\hline \multirow[b]{3}{*}{ Protein } & \multirow[b]{3}{*}{ Group } & \multirow[b]{3}{*}{$n$} & \multicolumn{5}{|c|}{ Wk of lactation } & \multicolumn{2}{|c|}{$\begin{array}{l}\text { Supplementa- } \\
\text { tion effect }\end{array}$} \\
\hline & & & \multicolumn{2}{|c|}{5} & \multirow[b]{2}{*}{$p^{\dagger}$} & \multicolumn{2}{|c|}{25} & \multirow{2}{*}{$\begin{array}{c}\text { Within } \\
\text { group } \neq \\
(p)\end{array}$} & \multirow{2}{*}{$\begin{array}{l}\text { Between } \\
\text { groups§ } \\
(p)\end{array}$} \\
\hline & & & Mean & SD & & Mean & $\mathrm{SD}$ & & \\
\hline \multicolumn{10}{|c|}{ Lactoferrin } \\
\hline \multirow[t]{2}{*}{$\mathrm{g} / \mathrm{L}$} & A & 31 & 1.37 & 0.86 & NS & 0.98 & 0.83 & $<0.05$ & NS \\
\hline & B & 25 & 1.46 & 0.65 & & 1.07 & 0.48 & $<0.05$ & \\
\hline \multirow[t]{2}{*}{$g / 24 h$} & A & 31 & 0.95 & 0.68 & NS & 0.77 & 0.59 & NS & NS \\
\hline & B & 25 & 0.94 & 0.39 & & 0.84 & 0.38 & NS & \\
\hline \multicolumn{10}{|l|}{ SIgA } \\
\hline \multirow[t]{2}{*}{$g / L$} & A & 30 & 0.93 & 0.34 & NS & 0.92 & 0.51 & NS & $<0.05$ \\
\hline & B & 25 & 1.00 & 0.35 & & 0.75 & 0.33 & $<0.05$ & \\
\hline \multirow[t]{2}{*}{$\mathrm{g} / 24 \mathrm{~h}$} & A & 30 & 0.63 & 0.26 & NS & 0.73 & 0.46 & NS & $<0.05$ \\
\hline & B & 25 & 0.66 & 0.25 & & 0.57 & 0.26 & NS & \\
\hline
\end{tabular}

* The 24-h output of the proteins is also shown. A, high-caloriesupplemented group; B, low-calorie-supplemented group.

$\dagger$ Value for the two groups at the initiation of the supplementation.

$\ddagger$ The effect of the diet within each group is the individual difference during the $20 \mathrm{wk}$ of supplementation, i.e. from wk 5 to 25 postpartum (Wilcoxon signed-rank test), with an expected central location value of zero.

$\S$ The effect of the diet compared between the two groups (MannWhitney $U$ test): two-sample central location test. The significance value $p$ is given for both statistical analyses. 
SIgA in groups A and B were comparable $(p>0.05)$ at the initiation of the study. In group $A$, the concentration did not vary between wk 5 and 25 , but group B showed a significant decrease at wk $25(p>0.05$. Table 1). At the end of the supplementation period. group B showed a significantly lower value than group A (Table 1).

The daily SIgA output did not differ between groups A and B at the initiation of the supplementation period $(p>0.05)$ but became significantly lower in group B at wk $25(p<0.05)$, although it remained within the normal range.

Antibody levels. The levels of milk IgA antibodies against $E$. coli $\mathrm{O} 6$ showed fluctuations between the various sampling weeks. The $p$ values for the fluctuations along the weeks are not shown, only those in wk 5 and 25 (Table 2), i.e. at the onset and at the end of the supplementation period. The median values and ranges for all the weeks are shown in Table 3 . For the high calorie supplemented group (group A), there was a significant increase from wks 10 and 20 to $w \mathrm{k} 25$. However, no effect of the supplementation, measured as the difference between wk 5 and 25 , was found within this group (Table 2, $p>0.05$ ). The low calorie-supplemented group (group B), also showed a significant increase in the antibody levels between wk 10 and 20,10 and 25 , and 20 and 25 (all $p$ values $<0.05$, data not shown), as well as between wk 5 and 25 (Table 2). There was no significant difference in the levels of $E$. coli anti-O6 between the two groups at any of the times tested postpartum (Table 2).

In group $\mathrm{A}$, the anti- $E$. coli 10 pool levels showed significant decreases between wk 5 and 10 and between wk 5 and 20; in group B, a decrease in antibody levels was found only between wk 5 and 10 .

For the tetanus antibody levels, the initial values were comparable in the two groups. There was a significant increase in the levels in group A from wk 5 to 25 (Table 2). A significant increase in the levels was also observed for wk 10 to 20 and 10 to 25 . In group B, a significant increase was only observed between wk 10 to 25 ( $p$ values not shown).

No significant difference was obtained between the two groups for any of the antigens investigated (Table 2).

Table 2. Statistical analysis of effect of supplementation within each group and between groups $A$ and $B$ for IgA-specific levels and avidities*

\begin{tabular}{|c|c|c|c|c|c|}
\hline \multirow[b]{2}{*}{ Antigen } & \multirow[b]{2}{*}{ Antibody } & \multirow[b]{2}{*}{ Group } & \multicolumn{3}{|c|}{ Supplementation effect } \\
\hline & & & $n$ & $\begin{array}{l}\text { Within group } \dagger \\
(p)\end{array}$ & $\begin{array}{c}\text { Between groups } \neq \\
(p)\end{array}$ \\
\hline \multirow[t]{4}{*}{ E. coli O6 } & Level & A & 31 & NS & NS \\
\hline & & B & 27 & $<0.05$ & \\
\hline & Avidity & A & 30 & NS & NS \\
\hline & & B & 24 & NS & \\
\hline \multirow[t]{4}{*}{ E. coli 10 pool } & Level & A & 16 & NS & NS \\
\hline & & B & 15 & NS & \\
\hline & Avidity & A & 16 & NS & NS \\
\hline & & B & 15 & $<0.05$ & \\
\hline \multirow[t]{4}{*}{ Tetanus } & Level & A & 29 & $<0.05$ & NS \\
\hline & & B & 25 & NS & \\
\hline & Avidity & A & 26 & NS & NS \\
\hline & & B & 19 & NS & \\
\hline
\end{tabular}

* The values taken into account are the differences between the values at wk 5 and 25 (i.e. at the onset and at the end of the supplementation period)

t The effect of the diet within each group is the individual difference during the $20 \mathrm{wk}$ of supplementation, i.e. at wk 5 and 25 postpartum (Wilcoxon signed-rank test), with an expected central location value of zero.

¥ The effect of the diet on the two groups is analyzed comparing individual differences at wk 5 and 25 of lactation (Mann-Whitney $U$ test): two-sample central location test.
Antibody avidities. The avidity of the antibodies to the three antigens studied showed no significant effect relating to the two different supplementation levels, but there was a tendency to an increase with time, especially for group A. In group B, the avidity indices for the tetanus antibodies also tended to increase, but those against the $E$. coli 10 pool became significantly lower at wk 25 compared with wk 5 ( $p<0.05$. Table 2$)$. A decrease was also observed from wk 10 to $20(p<0.05)$. The avidity indices for the IgA anti-E. coli O6 showed no significant differences between the various weeks of sampling and between the groups $A$ and $B$ (Table 2). Median values and ranges are shown in Table 3.

\section{DISCUSSION}

The milk lactoferrin levels between the two groups of undernourished mothers were comparable to the ones reported previously, including the decrease during the first $12 \mathrm{wk}$ of lactation $(32,35)$. Decreased SIgA concentration and daily $\operatorname{SIgA}$ output were the only findings associated with low-compared with the high-caloric supplementation treatment, although in both groups the women showed SIgA levels within the normal range $(1,32)$. The values of SIgA reported here are comparable to those found among Guatemalan rural women at 1 mo of lactation (36). In the latter study, the mean concentrations observed at 3 mo of lactation tended to be lower than those at $1 \mathrm{mo}$, but the tendency did not attain statistical significance, possibly because of small sample size. It is clear that, in the present study, the group of women who received a low-caloric supplement had a significantly lower quantity of SIgA after 25 wk of lactation. This indicates that caloric supplementation of undernourished lactating mothers prevents a deterioration of the milk SIgA output.

We noted two significant differences in the antibody levels. Group A showed what might be regarded as a positive treatment effect on the antibody production against the tetanus toxoid. The milk antibodies against this antigen most likely originate from memory cells, stemming mainly from previous vaccination, although a study in India has suggested that "natural" intestinal exposure to tetanus may induce antibody responses (37). The other difference was observed in group $B$, in which a large increase in the antibody production against $E$. coli $\mathrm{O} 6$ occurred at the end of the supplementation period. This effect is not clearly associated with nutritional treatment but may be related to reinfection of $E$. coli $\mathrm{O} 6$. A selective exposure to the O6 antigen in group B. however, is unlikely because the mothers of both groups lived in the same geographic area. Independent of the triggering factor, it was possible for the undernourished mothers with the low-calorie supplementation to increase their levels of antibodies in spite of their deficient nutritional status.

During the supplementation period, there were significant fluctuations in some of the specific antibody levels. The fluctuations were noted for antibodies to all three antigens studied and may be due to several factors beyond the nutritional situation, including varying antigen exposure, possibly adding polyclonal stimulation by $\mathrm{O}$ antigens, variations in milk volume, the state of hydration of the mother, or possibly effects of intercurrent infections. Antibody levels showed no significant differences between the two supplemented groups. A similar pattern of fluctuation of milk IgA antibodies was observed also in earlier studies (36).

The antibody avidity indices showed more stable and constant results during the supplementation period than the antibody levels. We found no correlation between the antibody levels and the avidity indices of those antibodies. The only significant difference in avidity was a decrease in group B against the $E$. coli 10 pool antigens. We consider the probability of exposure to these antigens to be high, as they represent a mixture of 10 common bacterial serotypes. The avidity index for antibodies against this antigen pool was lower in both groups (Table 3) than the levels reported by Roberton et al. (30) in Pakistani (2.5 M) 
Table 3. Median levels, avidity index values, and ranges of IgA antibodies in milk samples against E. coli O6. E. coli IO pool, and tetanus toxoid antigens for the different weeks evaluated*

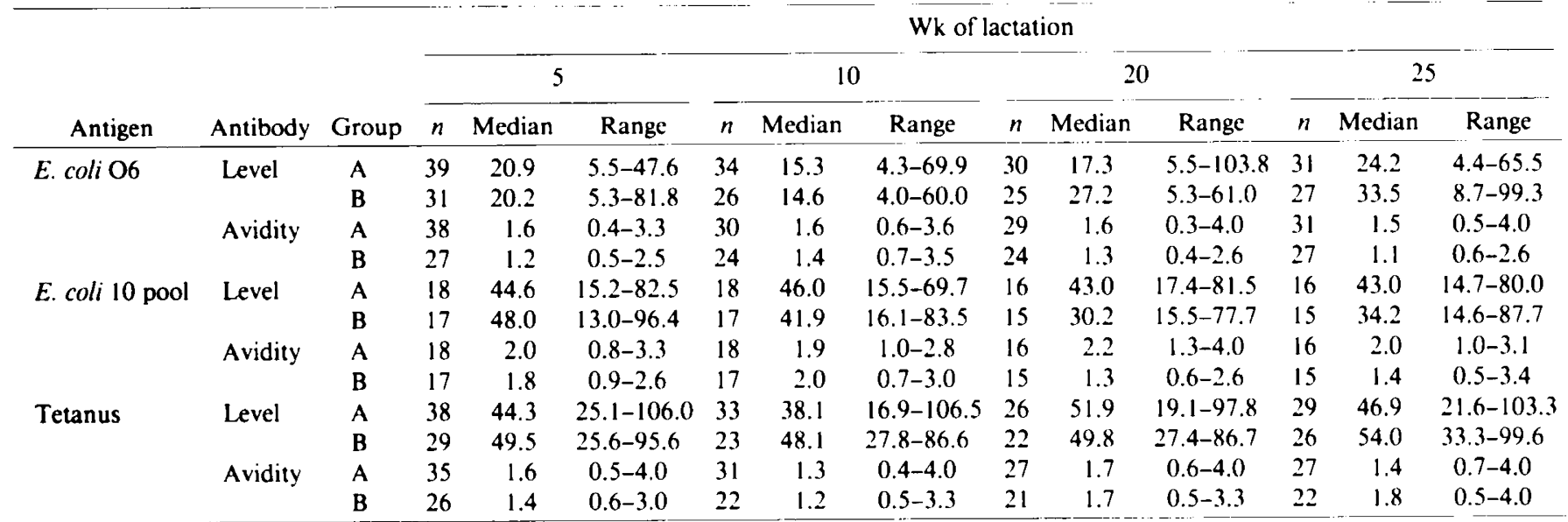

* A, high-calorie-supplemented group; B, low-calorie-supplemented group. The level of IgA-specific antibodies is expressed in percentage of a human milk standard pool; the avidity index values are expressed as the molarity of KSCN required to elute $50 \%$ of the antibodies.

and Swedish (3.1 M) mothers. The exact reasons for the lower avidity among the Guatemalan mothers are unknown. On the other hand, the median avidity results (Table 3 ) for anti-E. coli O6 were comparable to the ones obtained from well-nourished Costa Rican $(1.3 \mathrm{M})$ and Swedish $(1.4 \mathrm{M})$ mothers in a recent study (38). The basis for the observed fluctuations between the two groups in the avidity indices for the antibodies tested remain unclear to us, although it may relate to geographic differences in exposure to the $E$. coli serotypes used in the 10 pool. We feel that it is important to evaluate the effect of antigenic stimulation during lactation for a better understanding of the relationships between milk antibody levels and their avidities.

In conclusion, we found that SIgA was higher in the highcalorie-supplemented group. We were not able to show an improvement in the antibody response to specific antigens. The avidity of milk antibodies and their expression were not improved with the caloric supplement, but supplementation prevented the decrease in the content of total SIgA in milk. The fact that specific antibody levels were not hampered and could even increase in spite of the undernutrition may be especially important, because it has been shown that protection in the breast-fed infant against cholera (5), ETEC (7), and Campylobacter (4) is related to the specific SIgA antibody levels in the mother's milk. The relevance of milk-mediated protection may be illustrated by the fact that breast-feeding shows a striking protection against the two infections that are among the most common causes of death in early life in a poor community: diarrhea and neonatal septicemia $(3,39)$.

Acknowledgments. The authors thank Monika EricssonSchmidt, Lisbeth Larsson, and Behrit Bảhr for their assistance in part of the laboratory determinations and also biostatician Dr. Johan Karlberg for his invaluable statistical help. The study was supported by SAREC (Swedish Agency for Research Cooperation with Developing Countries), the Ellen, Walter, and Lennart Hesselman's Foundation, and by the Regional Office for Central America and Panama (ROCAP) of the US Agency for International Development.

\section{REFERENCES}

1. Lönnerdal B 1985 Biochemistry and physiological function of human milk proteins. Am J Clin Nutr 42:1299-1317

2. Prentice A. Paul AA 1990 Contribution of breast-milk to nutrition during prolonged breast-feeding. In: Atkinson SA. Hanson LÄ, Chandra RK (eds) Human Lactation 4. Breastfeeding. Nutrition. Infection and Infant Growth in Developed and Emerging Countries. ARTS Biomed Publ Distr Ltd. St. John's, Newfoundland, pp 87-101

3. Victora CG, Vaughan JP. Lombardi C, Fuchs SMC. Gigante LP, Smith PG,
Nobre LC. Teixeira AMB, Moreira LB, Barros FC 1987 Evidence for protection by breast-feeding against infant deaths from infectious diseases in Brazil. Lancet 2:319-322

4. Ruiz-Palacios GM, Calva JJ, Pickering LK. Lopez-Vidal Y. Volkow P. Pezzarossi H. Stewart West M 1990 Protection of breastfed infants against $\mathrm{Cam}^{\mathrm{a}}$ pylohacter diarrhea by antibodies in human milk. J Pediatr 116:707-713

5. Glass RI, Svennerholm AM. Stoll BJ, Khan MR, Belayet Hossain KM, I Huq $M$. Holmgren J 1983 Protection against cholera in breast-fed children by antibodies in breast milk. N Engl J Med 308:1389-1392

6. Hanson L $\dot{A}$. Adlerberth I. Carlsson B. Dahlgren U. Hahn-Zoric M. Mellander L. Morikawa I, Narayanan I, Nilsson K. Roberton D, Wold A. Zaman S. Jalil F 1990 Breast milk's attack on microbes: is it of clinical significance? In: Atkinson SA. Hanson LA. Chandra RK (eds) Human Lactation 4. Breastfeeding. Nutrition. Infection and Infant Growth in Developed and Emerging Countries. ARTS Biomed Publ Distr Ltd. St. John's. Newfoundland, pp 55-65

7. Cruz JR, Gil L. Cano F, Cáceres P. Pareja G 1988 Breast milk anti-Escherichia coli heat-labile toxin $\lg A$ antibodies protect against toxin-induced infantile diarrhea. Acta Paediatr Scand 77:658-662

8. Spik G, Cheron A. Montreuil J. Dolby JM 1978 Bacteriostasis of a milksensitive strain of Escherichia coli by immunoglobulins and iron-binding proteins in association. Immunology 35:663-671

9. Chandra RK 1979 Interactions of nutrition, infection and immune response: immunocompetence in nutritional deficiency. methodological considerations and intervention strategies. Acta Paediatr Scand 68:137-144

10. Tomkins $A M 1986$ Symposium on nutrition and resistance to infection: protein-energy malnutrition and risk of infection. Proc Nutr Soc 45:289304

11. Fakhir S, Ahmand P, Faridi MA. Rattan A 1989 Cell-mediated immune responses in malnourished host. J Trop Pediatr 35:175-178

12. Nohr CW, Tchervenkov JI, Meakins JL. Christou NV 1986 Malnutrition and humoral immunity: long-term protein deprivation. J Surg Res 65:381-386

13. Redmond HP. Leon P. Lieberman MD. Hoffman K. Shou J, Reynolds JV. Goldfine J, Johnston RB. Daly M 1991 Impaired macrophage function in severe protein-energy malnutrition. Arch Surg 126:192-196

14. Chandra RK 1975 Reduced secretory antibody response to live attenuated measles and poliovirus vaccines in malnourished children. $\mathrm{Br}$ Med J 2:583585

15. Sirisinha S, Suskind R. Edelman R. Asvapaka C. Olson RE 1975 Secretory and serum IgA in children with protein-calorie malnutrition. Pediatrics 55:166-170

16. Cruz JR, Carlsson B, Garcia B, Gebre-Medhin M. Hofvander Y. Urrutia JJ. Hanson LA 1982 Studies on human milk. III. Secretory lgA quantity and antibody levels against Escherichia coli in colostrum and milk from underprivileged and privileged mothers. Pediatr Res 16:272-276

17. Cruz JR. Hanson L 1986 Specific milk immune response of rural and urban Guatemalan women to oral immunization with a food protein. J Pediatr Gastroenterol Nutr 5:450-454

18. Cruz JR, Carlsson BVM, Hofvander Y. Holme DT. Hanson LA 1985 Studies of human milk II. Concentration of antibodies against Salmonella and Shigella in milk of women from different populations and the daily intake by their breast-fed infants. Acta Paediatr Scand 74:338-341

19. Carlsson B, Ahlstedt S. Hanson L. Lidin-Janson G. Lindblad BS 1976 Escherichia coli $\mathrm{O}$ antibody content in milk from healthy Swedish mothers and mothers from a very low socio-economic group of a developing country. Acta Paediatr Scand 65:417-423

20. Prentice A. Prentice AM. Cole TJ. Whitehead RG 1983 Determinants of variations in breast milk protective factor concentrations of rural Gambian mothers. Arch Dis Child 58:518-522 
21. Reddy V, Bhaskaram C. Raghuramulu N, Jagadeesan V 1977 Antimicrobial factors in human milk. Acta Paediatr Scand 66:229-232

22. Miranda R, Saravia NG, Ackerman R, Murphy N, Berman S, McMurray DN 1983 Effect of maternal nutritional status on immunological substances in human colostrum and milk. Am J Clin Nutr 37:632-640

23. Steward MW 1981 The biological significance of antibody affinity. Immunol Today 2:134-140

24. Steward MW 1977 Affinity of the antibody-antigen reaction and its biological significance. In: Glynn LE. Steward MW (eds) Immunochemistry: An Advanced Textbook. John Wiley \& Sons Ltd. Chichester, UK, pp 233-262

25. González-Cossio T, Flores F, Arciu Group 1992 Validity of maternal calf circumference to identify risk of intrauterine growth retardation. FASEB 6:A 1683(abstr)

26. Guo S, Roche AF, Chumlea WMC, Miles DS. Pohlman RL 1987 Body composition predictions from bioelectric impedance. Hum Biol 59:221-233

27. Holmgren J 1970 Studies of methods for quantitation of agglutinins and precipitins to Escherichia coli $\mathrm{O}$ and $\mathrm{K}$ antigens. Int Arch Allergy 37:380394

28. Mellander L, Carlsson B, Hanson LA் 1984 Appearance of secretory IgM and IgA antibodies to Escherichia coli in saliva during early infancy and childhood. J Pediatr 104:564-568

29. Pullen GR. Fitzgerald MG, Hosking CS 1986 Antibody avidity determination by ELISA using thiocyanate elution. J Immunol Meth 86:83-87

30. Roberton DM, Carlsson B. Coffman K. Hahn-Zoric M, Jalil F, Jones C Hanson LA 1988 Avidity of IgA antibody to $E$. coli polysaccharide and diphtheria toxin in breast milk from Swedish and Pakistani mothers. Scand $\mathrm{J}$ Immunol 28:783-789
31. Sohl Ảkerlund A, Hanson LA், Ahlstedt S, Carlsson B 1977 A sensitive method for specific quantitation of secretory lgA. Scand J Immunol 6:1272-1282

32. Goldman AS, Garza C, Nichols BL, Goldblum RM 1982 Immunologic factors in human milk during the first year of lactation. J Pediatr 100:563-567

33. Mancini G. Carbonara AO. Heremans JF 1965 Immunochemical quantitation of antigens by single radial immunodiffusion. Immunochemistry 2:235-254

34. Colton T 1974 Statistics in Medicine. Little Brown and Company, Boston, pp 219-227

35. Lönnerdal B. Forsum E. Gebre-Medhin M. Hambraeus L 1976 Breast milk composition in Ethiopian and Swedish mothers. II. Lactose, nitrogen, and protein contents. Am J Clin Nutr 29:1134-1141

36. Cruz JR, Arévalo C, Hanson LÁ 1986 Effects of ethnicity on immunologic components in human milk. In: Hamosh M. Goldman AS (eds) Human Lactation. 2. Maternal and Environmental Factors. Plenum Press, New York, pp 569-579

37. Dastur FD, Awatramani VP, Dixit SK, D'sa JA, Cooverji ND. Anand MP 1981 Response to single dose of tetanus vaccine in subjects with naturally acquired tetanus antitoxin. Lancet 2:219-222

38. Hanson LA. Jalil F. Ashraf R. Bernini S. Carlsson B. Cruz J. González T. Hahn-Zoric M. Mellander L, Minoli Y. Moro G, Nave F. Zaman S. Mata L. Karlberg J. Lindblad B 1991 Characteristics of human milk antibodies and their effect in relation to the epidemiology of breastfeeding and infection in a developing country. In: Mestecky J (ed) Immunology of Milk and the Neonate. Plenum Press, New York, pp 1-15

39. Ashraf R. Jalil F, Zaman S. Karlberg J, Khan S, Lindblad BS, Hanson LA 1991 Breast feeding and protection against neonatal sepsis in a high risk population. Arch Dis Child 66:488-490 